\title{
THE EFFECT OF LIME, PHOSPHATE AND POTASSIUM ON THE GROWTH OF WHITE CLOVER- AND LOTUS- BASED PASTURES ON PAKIHISOILS
}

\author{
J. D. Morton
}

Agricultural Research Division, MAF, Greymouth

\section{Abstract}

A series of trials was conducted on a Mawhera gley podzol to investigate the comparative establishment and yield of white clover/ryegrass and lotus/Yorkshire fog pastures at different rates of lime, phosphate and potassium. Lotus/Yorkshire fog was superior in yield to white clover/ryegrass at all rates of lime and fertilizer, in the second and third year after sowing. This superiority was more marked at low rates of lime. The potential role of lotus as a pioneer species on pakihi soils is discussed.

\section{INTRODUCTION}

THERE are an estimated 200000 ha of wet terrace-land soiis known as pakihi soils on the West Coast. These soils are naturally strongly acid, deficient in many essential plant nutrients, and have impeded vertical drainage. An estimated 15000 ha of pakihi soils have been aerially oversown with white clover and grasses.

Earlier research at Bald Hill showed that improved Lotus pedunculatus required lower rates of lime and supephosphate for establishment than white clover (During et al., 1964). These workers considered that a Lotus pedunculatus-based pasture with Yorkshire fog as the dominant companion grass would be best suited to the environment, cheaper to maintain, and would probably form a surface mat resistant to pugging.

More recent work on an Okarito soil at Mawheraiti (Morton, in press) showed that yields from both G 4705 (Maku) and G 4703 lotus-based pastures were substantially greater than from white clover-based pastures at low initial rates of phosphate $(40 \mathrm{~kg} / \mathrm{ha})$ and lime (0.5 t/ha), 
This series of trials was commenced in 1976 to further investigate the comparative establishment and yield of white clover/ryegrass and lotus/Yorkshire fog pastures at different rates of potassium, lime and phosphate.

\section{EXPERIMENTAL}

The trials were located near Awatuna $(30 \mathrm{~km}$ south of Greymouth) on a Mawhera relict podzol gley soil (Ross and Mew, 1975). Soil tests showed that the mineral fertility and soil $\mathrm{pH}$ of the site were very low. The original cover of silver pine (Dacrydium colensoi) had been logged, resulting in a vegetative cover of predominantly umbrella fern (Gleichenia circinata) and pakihi rush (Cladium teretifolium) which had been continually burnt.

Two of the trials had a split plot design with two replicates with rates of lime and phosphate as main plots and pasture type as subplots. Statistical analysis combining results from these two trials used treatment means as input to a split plot analysis of variance, treating trials as replicates. The third trial had a split plot design with four replicates with rates of potassium as main plots and pasture type as subplots. Plot size was $4 \times 1.5 \mathrm{~m}$ with $1 \mathrm{~m}$ buffers between plots.

Main plot treatments were:

(a) Lime $\mathrm{x}$ phosphate trial: Lime was applied at sowing only at 500 or $2000 \mathrm{~kg} / \mathrm{ha}(500 \mathrm{~L}, 2000 \mathrm{~L})$ and monocalcium phosphate (MCP) applied annually at 20 or $80 \mathrm{~kg} \mathrm{P} / \mathrm{ha}$ (20 P, $80 \mathrm{P})$,

(b) Potassium trial: Potassium chloride $(\mathrm{KCl})$ was applied annually at $35,70,105$ and $140 \mathrm{~kg} \mathrm{~K} / \mathrm{ha}$.

Approximately $60 \%$ of the MCP and KC1 was applied in September and $40 \%$ in February. Calcium sulphate, elemental sulphur and magnesium oxide were applied to both trials initially and annually, while trace elements $(\mathrm{Cu}, \mathrm{Mo}, \mathrm{B}, \mathrm{Co})$ were applied initially. In the lime $\mathrm{X}$ phosphate trials, $20 \mathrm{~kg} \mathrm{P} / \mathrm{ha}$ was applied to all treatments five months after sowing to improve pasture establishment at the lowest rate of phosphate. KC1 (115 kg/ha) was also applied about this time and reapplied in September (120 $\mathrm{kg} / \mathrm{ha}$ ) and February (80 kg/ha), In the potassium trial, lime was applied at sowing only at $3.75 \mathrm{t} / \mathrm{ha}$ while MCP was applied at $75 \mathrm{~kg} \mathrm{P} / \mathrm{ha}$ in the second and third years.

Pasture types consisted of the following cultivars:

(a) 'Grassland Huia' white clover (5 kg/ha) and 'Grasslands Ruanui’ ryegrass $(10 \mathrm{~kg} / \mathrm{ha})$. 
(b) 'Grasslands Maku' lotus and Yorkshire fog.

In the lime and phosphate trial the seeding rate of lotus and Yorkshire fog was adjusted to give equivalent seed numbers to the seeding rate of white clover and ryegrass. Seeding rates of lotus and Yorkshire fog in the potassium trial were $5 \mathrm{~kg} / \mathrm{ha}$ and 10 $\mathrm{kg} / \mathrm{ha}$, respectively, without adjustment to give similar seed numbers to white- clover and ryegrass. A commercial strain of Yorkshire fog was used in the potassium trial and 'Massey Basyn' Yorkshire fog was used in the lime and phosphate trials. All legume seed was inoculated with heavy rates of commercial peat inoculant 20 hours before the seed was applied. Lime was applied on 15 September, fertilizer on 16 September, and seed on 23 September 1976 for the potassium trial. For the lime X phosphate trials, lime was applied on 7 September, fertilizer on 16 September, legume seed on 21 September and the grass seed on 18 October 1977.

Legume seedling vigour was assessed on a 0 to 5 scale (Lowther, 1974) in all trials and legume and grass percentage establishment measured in the lime $\mathrm{x}$ phosphate trials. The plots were mown at monthly intervals from September to May and total dry matter yields measured. All the clippings (minus those required for dry matter samples) were returned to each plot. Dissections for the determination of species dry matter yields were carried out for one spring and one autumn cut.

The potassium trial terminated on 17 April 1979 and the lime $\mathrm{X}$ phosphate trial on 26 April 1980, yield measurements being carried out for three seasons.

TRIAL RESULTS

\section{Lime and Phosphate Triat}

\section{Legume Seedling Vigour}

Lotus seedling vigour was significantly greater $(P<0.05)$ than white clover at the low rate of phosphate $(1.94 \mathrm{cf} .1 .46$ at $500 \mathrm{~L}$ $20 \mathrm{P}$ ). This trend was reversed at the high rate of phosphate.

\section{Legume Establishment}

Lotus establishment was significantly higher than white clover establishment $(P<0.01)$ at the low rate of lime $(44.1 \% c f$. $18.2 \%$ at $500 \mathrm{~L} 20 \mathrm{P})$. There were only small differences in legume establishment at the high rate of lime. 


\section{Grass Establishment}

Yorkshire fog establishment was significantly higher $(\mathrm{P}<$ $0.01)$ than ryegrass establishment at the low rate of lime $(15.2 \%$ cf. $6.2 \%$ at $500 \mathrm{~L} 20 \mathrm{P}$ ). The differences in grass establishment were small and non-significant at the high rate of lime.

\section{Total Yield}

The mean dry matter yield for the second and third years from lotus/Yorkshire fog was significantly greater than from white clover/ryegrass at the low rate of lime (Table 1). At the high rate of lime the difference was non-significant.

TABLE 1: EFFECT OF LIME AND PHOSPHATE ON MEAN DRY MATTER YIELD (kg/ha) OF TWO PASTURE TYPES FROM SECOND AND THIRD YEARS AFTER SOWING.

\begin{tabular}{rcc}
\hline & $\begin{array}{c}\text { White clover/ } \\
\text { Ryegrass }\end{array}$ & $\begin{array}{c}\text { Limesphate } \mathbf{x} \text { Cultivar } \\
\text { Lotus/ } \\
\text { Yorkshire }\end{array}$ fog \\
\hline 500 L 20 P & 980 & 2790 \\
500 L 80 P & 1450 & 4020 \\
2000 L 20 P & 2060 & 3050 \\
2000 L 80 P & 3610 & 4380 \\
\hline
\end{tabular}

LSD (5\%) for horizontal comparisons $=1660$

$\operatorname{LSD}(5 \%)$ for vertical comparisons $=2360$

\section{Species Yield}

Species dry matter yields from a spring cut are presented in Fig. 1 , typifying the species yield. The differences in yield between white clover and lotus were nun-significant, although there was a tendency for lotus to be superior at low rates and white clover to be superior at high rates of lime and phosphate. There were larger differences between the grasses, with Yorkshire fog significantly outyielding ryegrass at all except the high rate of lime and phosphate.

\section{Potassium Trial}

In the potassium trial the seedling vigour of white clover was significantly greater than lotus at all rates of potassium (3.00 cf. 2.35). The mean dry matter yield for the second and third years from lotus/Yorkshire fog $(5490 \mathrm{~kg} / \mathrm{ha})$ was significantly greater (P $<0.01)$ than for white clover/ryegrass $(3560 \mathrm{~kg} / \mathrm{ha})$ at all rates of potassium. There was no response in yield to potassium from either pasture type. 


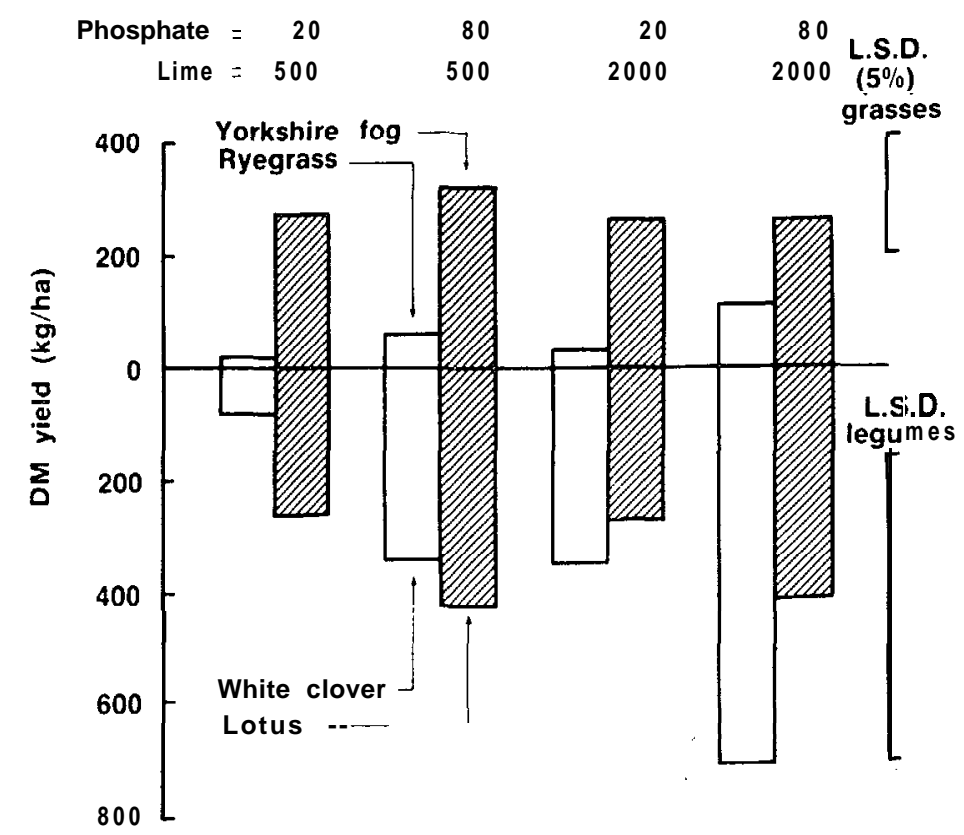

FIG. 1: Species dry maffer yields from a spring cut.

\section{DISCUSSION}

The results from the lime $X$ phosphate trial show that a mixture of lotus and Yorkshire fog established better and was higher yielding than white clover and ryegrass at low initial rates of lime and phosphate. Similar results for both lime and phosphate were obtained by Lowther (1976) on a low fertility, acid tussock grassland soil, while Brock (1973) found that Maku outyielded white clover under conditions of low phosphate. The superiority of the lotus/Yorkshire fog pasture appeared to be due to the tolerance of both lotus and Yorkshire fog to low rates of lime. Yorkshire fog in particular did not appear to respond to either lime or phosphate and its marked superiority over ryegrass suggests that it may be a more suitable grass on pakihi soils. The data suggest that, with lotus/Yorkshire fog, initial lime application may be reduced to $500 \mathrm{~kg} / \mathrm{ha}$, The optimum rate of phosphate is not well defined but a worthwhile increase in yield may be obtained from applying maintenance rates of phosphate above $20 \mathrm{~kg} \mathrm{P} / \mathrm{ha}$. 
In the potassium trial there were high basal applications of phosphate (average of $60 \mathrm{~kg} \mathrm{P} / \mathrm{ha} / \mathrm{yr}$ ) and a high initial application of lime $(3750 \mathrm{~kg} / \mathrm{ha})$. Nevertheless, both lotus and Yorkshire fog were substantially higher yielding than white clover and ryegrass, respectively. The difference was more marked than in the high $\mathrm{P}$, high lime treatment of the lime $\times$ phosphate trials.

Neither pasture type nor any of the cultivars responded to potassium. This was in contrast to the large yield responses to potassium found in a small plot mowing trial on the Addison soil at Bald Hill (Wright and Morton, 1976). Soil potassium levels were low in each soil and the discrepancy may be best explained by the return of 90 to $100 \%$ of the clippings in this trial compared with only 60 to $70 \%$ of the clippings in the Bald Hill trial. The return of more clippings would be expected to result in more efficient cycling of the potassium applied and thus a reduced response.

\section{PRACTICAL IMPLICATIONS}

These research results, observation and farmer experience on several lotus blocks show that lotus can be useful on pakihi and other poorly drained soils.

There are an estimated 100000 ha of pakihi soils on the West Coast where it is difficult for an oversown white clover-based pasture to achieve its potential for various reasons. First, pasture growth and utilization can be limited on the wetter of these soils where time is required for surface drainage, pasture establishment and consolidation by sheep to dry out the ground and allo-w access to the wetter areas. This time span also enables machinery to remove stumps and timber by rootraking. Secondly, aerial spraying of gorse can result in suppression of clover growth after the pasture has been established. Another reason can be delays in subdivision and a shortage of stock to graze the established pasture, resulting in a reduction in pasture yield from the second year after sowing.

These trials and earlier work (Morton, in press) show that it is possible to use lotus as a pioneer legume at low rates of lime, phosphate and potassium until gorse control, drainage and subdivision have been carried out. The lotus may then be replaced by oversowing with a white clover-based pasture using higher rates of lime and phosphate in order to achieve higher yields. If the lotus is only slightly damaged by post development operations such as gorse control, another option is to retain it as the major legume, and increase its yield by the application of higher main- 
tenance rates of phosphate. Limited farmer experience has shown that lotus will persist and grow satisfactorily on pakihi soils under a rotational grazing system using cattle.

Observation on lotus establishment and growth on areas, which despite drainage still remain wet, indicate that it has advantages on these sites over white clover. However, in practice, it would probably be difficult to maintain lotus as the dominant legume species because of its inability to compete with white clover which could be introduced from other paddocks in dung. Work by Lowther (1976) and Brock and Charlton (1978) has shown that white clover will suppress lotus when both are sown in a mixture.

The use of a lotus/Yorkshire fog seed mixture is limited at present by the high price of lotus seed and the lack of availability of Yorkshire fog seed. Until the situation changes, Yorkshire fog could be substituted by cocksfoot or a perennial ryegrass. Previous work (Morton, in press) has shown that, at lower rates of lime and fertilizer, both grasses contributed a lower proportion of total yield than Yorkshire fog did in these trials. Although this shortfall was compensated for by increased lotus growth, a reasonable contribution from grasses is desirable for winter and early spring growth.

From the economic aspect, the use of lotus as a pioneer species has the advantage of spreading the high initial costs of development over a longer period. There is also a large cost saving if the lime and fertilizer required to establish the white clover-based pasture can be ground instead of aerial spread. This can be achieved where drainage, consolidation and rootraking have dried the ground sufficiently to allow the passage of ground spreading machinery.

\section{CONCLUSION}

A lotus/Yorkshire fog pasture was higher yielding than a white clover/ryegrass at low rates of lime, phosphate and potassium. Thus, both lotus and Yorkshire fog could play an important role in the development of pakihi soils.

\section{ACKNOWLEDGEMENTS}

C. J. Chunn, R. E. Gamble and D. J. Paterson for technical assistance, Mrs A. J. Lister, D. J. Saville and Miss S. Rogers for statistical analysis and interpretation. 


\section{REFERENCES}

Brock, J. L., 1973. N.Z ॥lagric. Res., 16: 483-91

Brock, J. L.; Charlton, 'J. F. L., 1978. Proc. N .Z. Grassld A ss., 39: 121-9.

During, C.; da Roza, R.; Martin, D. I., 1964. Ibid., 26: 62-7.

Lowther, W. L., 1974. N.Z. Ill exp. Agric., 2: 145-9. 1976. Proc. N.Z. Grassld Ass., 38 (1): 133-9.

Ross, C. W.; Mew, G., 1975. Soil N ews, 23: 78-90.

Wright, D. B.; Morton, J. D., 1976. Proc. N.Z. Grassld A ss., 38 (1) : 19.30. 